\title{
Impact of Private Equity Trading Platforms on Firm Value and Corporate Govemance
}

\author{
Daehyeon Park, Graduate Student, Sungkyunkwan University \\ Doojin Ryu*, Professor, Sungkyunkwan University
}

\begin{abstract}
$\langle$ Abstract $\rangle$
This study presents a theoretical model to analyze the effect of private equity trading platforms, which have recently experienced rapid growth, on the investment decisions of unlisted companies. As the value of unlisted companies has soared, demand for these stocks has increased. Accordingly, platforms for the brokerage of private stock transactions are being activated. We find that these platforms increase the liquidity in the unlisted stock market by easing regulations on trading of these stocks, further enhancing the firm values and corporate governance of the corresponding firms. In addition, a significant number of unlisted companies are family-owned, in which a manager is also a blockholder. Our study therefore constructs a framework based on a market microstructure model to analyze the impact of unlisted stock trading platforms. In the case of an unlisted firm, a potential dual agency problem exists where the manager, who is also a blockholder, invests less than the external shareholders' profit-maximizing levels. We find that managers have the incentives to increase firms' investment when the liquidity in the unlisted stock market improves with the growth of the private equity trading platform, implying that these platforms potentially enhance corporate governance of unlisted companies and promote their growth.
\end{abstract}

Keywords: Capital Investment; Corporate Governance; Dual Agency Problem; Market Microstructure; Private Equity Trading Platform

JEL Classification: G14, G30, G34, G38

* Corresponding Author. Address: College of Economics, Sungkyunkwan University, 25-2, Sungkyunkwan-ro, Jongno-gu, Seoul, Korea 03063; E-mail: sharpjin@skku.edu; Tel: +82-2-760-0429; Fax: +82-2-760-0950.

Received: February 28, 2020; Revised: June 4, 2020; Accepted: June 18, 2020 


\title{
비상장주식거래 플랫폼이 기업 가치와 기업지배구조에 미치는 영향
}

\author{
박 대 현 (성균관대학교 대학원생) \\ 류 두 진 (성균관대학교 교수)*
}

\begin{abstract}
본 연구는 최근 활성화되고 있는 비상장주식거래 플랫폼의 현황과 기대효과를 개괄적으로 제시하고, 이에 대한 이론모형을 설계하여 해당 플랫폼의 활성화가 비상장기업의 자본투자 의사결정에 미치는 영향을 분석한다. 비상장기업의 가치가 급등함에 따라 관련 주식의 거래에 대한 수요가 증가하자 국내 외에서 비상장주식 거래를 전문적으로 중개하는 플랫폼이 활성화되고 있다. 해당 플랫폼은 비상장주식 거래에 대한 진입장벽을 낮춤으로써 비상장주식거래의 유동성을 높이고 있다. 주식거래의 유동성이 증가하면 거래대상 기업은 자본조달을 원활하게 할 수 있으며, 기업 가치와 기업지배구조도 개선된다. 본 논문에서는 시장미시구조 모형을 바탕으로 비상장기업의 지배구조가 창업주, 지배대주주, 경영자가 일치하는 형태임을 고려하여 비상장주식거래 플랫폼 도입의 효과를 분석하기 위한 모형을 설계한다. 비상장기업의 경우, 대주주인 경영자가 외부 주주의 이윤이 극대화되는 수준에 비해 적게 투자할 유인이 있는 이중 대리인 문제가 발생한다. 그러나 비상장주식거래 플랫폼이 활성화되어 유동성이 높아질 경우, 외부 주주의 이윤을 극대화하는 수준까지 장기투자를 늘릴 유인이 생긴다. 이는 비상장주식거래 플랫폼이 기업의 지배구조를 개선하고 성장을 촉진할 수 있음을 함의한다.
\end{abstract}

핵심 단어 : 기업지배구조, 비상장주식거래 플랫폼, 시장미시구조, 이중 대리인 문제, 자본투자 JEL 분류기호: G14, G30, G34, G38

* 연락담당 저자. 주소: 서울특별시 종로구 성균관로 25-2 성균관대학교 경제대학, 03063; E-mail: sharpjin@skku.edu; Tel: 02-760-0429; Fax: 02-760-0950. 


\section{1. 서론}

최근 혁신적인 사업모형(business model)을 제시하며 등장한 스타트업(start-up) 벤처기업과 중소 혁신기업은 급격히 성장하고 있다. 이러한 혁신기업 중 가치가 10 억 달러 이상인 비상장 기업은 유니콘 기업으로 분류되며 시장의 확장과 변화를 주도하고 있다. 미국의 우버(Uber), 에어비앤비(Airbnb), 핀터레스트(Pinterest) 등 참신한 비즈니스 모델을 통해 빠른 속도로 성장한 회사가 이에 해당한다. 국내의 경우 우아한형제들, 쿠팡, L\&P코스메틱, 크래프톤, 비바리퍼블리카, 야놀자, 위메프 등의 기업이 유니콘 기업으로 분류되며 시장을 주도하고 있다.1) 해당 기업의 급격한 성장세로 인해 비상장주식에 대한 투자자의 수요가 증가함에 따라 비상장주식거래를 중개하는 플랫폼에 관한 관심도 늘어나고 있다. 이에 따라 최근 활성화되기 시작한 비상장주식거래 플랫폼은 비상장기업의 성장에 긍정적인 영향을 미칠 것으로 보인다.

미국의 경우, 증권규제가 완화되어 비상장주식거래가 증가하고 있으며, 이에 따라 쉐어스포스트 (SharesPost)와 NPM(NASDAQ Private Market)처럼 전문투자자를 대상으로 하는 비상장 주식거래 플랫폼의 규모가 늘어나고 있다. 이러한 변화로 인해 미국의 유니콘 기업은 전 세계 유니콘 기업 규모의 약 절반을 차지할 정도로 성장하고 있다. 이와 마찬가지로 국내에서도 비상장 주식거래를 위한 플랫폼이 등장하고 있다. 한국거래소의 KONEX(Korea New Exchange)와 $\mathrm{KSM}(\mathrm{KRX}$ Start-up Market), 그리고 금융투자협회의 K-OTC와 K-OTC PRO 등이 이에 해당한다. 최근에는 이러한 플랫폼보다 진입장벽을 더욱 낮춰 기업의 부담을 줄이고, 일반 투자자의 비상장주식에 대한 접근성을 높인 플랫폼이 공개되고 있다. 증권사의 '비상장레이더', 코스콤의 ‘비마이유니콘', 핀테크 업체의 ‘증권플러스 비상장' 등과 같은 플랫폼은 등록 요건을 최소화함과 동시에 주주명부 또한 관리해주어 거래의 투명성과 신뢰성 또한 담보하고 있다. 일부 플랫폼의 경우 실시간으로 거래가 기록되는 블록체인(blockchain) 기술을 통해 투명성을 더욱 개선한다. 이처럼 다양한 비상장주식거래 플랫폼이 공개됨에 따라 일반 투자자의 비상장주식거래에 대한 유입이 더욱 증가할 것으로 전망된다.

비상장주식거래 플랫폼의 활성화는 두 가지 측면에서 기업의 성장에 긍정적인 영향을 미친다. 우선, 중소기업의 자본조달 문제를 완화할 수 있다. 중소기업의 경영 애로사항 중 가장 대표적인 것이 자본조달이다. 그러나 복잡한 절차를 요구할 뿐만 아니라 보수적으로 이루어지는 은행 대출은 기업에 적절한 자본조달의 창구로서 기능하기 힘들다. 반면, 주식거래는 유연한 자본 조달을 가능하게 한다. 이러한 점에서 비상장주식거래 플랫폼의 활성화는 비상장기업에 다양한 자본조달 경로를 제공하여 이들이 성장을 위해 자본에 대해 투자할 수 있는 여건을 제공한다. 그러나 자본조달이 쉬워지더라도 기업지배구조와 경영자의 대리인 문제 등으로 인해 적절한 수준의 자본투자로 이어지지 않을 가능성이 있다. 이와 관련하여 주식거래에서의 높은 유동성이 기업의 가치와 지배구조에 긍정적인 영향을 미친다는 다수의 선행연구는 비상장주식거래 플랫폼의 도입이 거래대상 기업에 긍정적인 영향을 미칠 수 있음을 시사한다. 이에 따라 본 논문은 비상장주식거래 플랫폼이 기업 가치 상승에 긍정적인 영향을 미칠 수 있는지를 살펴본다.

1) “나도 유니콘에 투자해볼까?'... 비상장 스타트업 주식거래 관심”, 조선비즈, 2020년 1월. 
Impact of Private Equity Trading Platforms on Firm Value and Corporate Governance

이를 위해 기업 가치에 직접적인 영향을 미치는 자본투자에 대한 경영자의 의사결정을 분석하고, 주식거래의 유동성이 비상장기업의 투자의사 결정에 미치는 영향을 검토한다.

본 연구에서는 시장미시구조에 관한 이론모형을 바탕으로 주식거래의 유동성 증가가 기업 가치와 기업지배구조에 미치는 영향을 자본투자 의사결정을 중심으로 분석한다. 특히 상당수 비상장기업의 지배구조가 창업주, 경영자, 지배주주가 일치하는 형태임을 고려하여, 대주주인 경영자가 기업의 투자에 관해 결정하는 형태로 모형을 구성한다. 모형을 바탕으로 주식거래의 유동성 증가가 경영자의 투자의사 결정에 미치는 영향을 분석한 결과, 유동성이 증가할수록 경영자가 기업 가치 상승을 위한 자본투자를 늘려나감에 따라 모든 주주의 이윤을 극대화하는 수준으로 투자하게 됨을 보인다. 이는 비상장주식거래 플랫폼의 도입으로 인한 비상장주식 거래의 유동성 증가가 비상장기업의 가치 상승으로 이어지며, 기업지배구조 또한 개선한다는 점을 보여준다. 본 연구의 분석은 지배주주와 경영자가 일치하는 형태의 기업에 초점을 맞추어, 금융시장 미시구조모형을 바탕으로 비상장기업의 지배구조를 설명할 수 있는 모형을 제시한다는 점에서 학술적 의의가 있다. 또한, 비상장주식거래 플랫폼을 통한 비상장주식거래 유동성 증가가 비상장기업의 기업 가치 상승의 중요한 요소임을 고려하여, 플랫폼에 대한 일반 투자자의 참여를 유도할 방안을 제시한다는 점에서 실무 및 정책적 함의를 갖는다.

본 연구의 구성은 다음과 같다. 제 2 장은 비상장주식거래 플랫폼의 도입 현황을 정리하고 그로 인한 기대효과를 살펴본다. 제 3장은 이론모형을 통하여 비상장주식거래 플랫폼의 도입이 기업의 자본투자에 미치는 영향을 분석한다. 제 4장은 비상장주식거래 유동성을 증가시키기 위해 비상장주식거래 플랫폼에 대한 일반 투자자의 참여를 높일 방안을 검토한다. 마지막으로 제 5 장은 연구의 전체적인 내용을 요약하고 결론을 제시한다.

\section{2. 비상장주식거래 플랫폼}

\section{1 국내외 비상장주식거래 플랫폼 도입 현황}

비상장 우량기업의 성장으로 비상장주식거래에 대한 수요가 늘어남에 따라, 중소기업이 비상장 주식거래를 통해 투자를 유치하는 경우가 증가하고 있다. 이에 미국은 JOBS(Jumpstart Our Business Startups) Act를 시행하여 증권규제를 완화함으로써 비상장 주식거래를 활성화 하였다.2) 상장기업에 요구되는 공시나 내부통제 없이 비상장기업이 자금을 조달할 수 있도록 한 것이다. 이에 따라 미국의 장외유통플랫폼인 쉐어스포스트와 NPM을 통한 거래 또한 확대되고 있다. 두 플랫폼은 기업공개 전(前) 단계의 비상장기업에 지분거래를 통한 유동성 공급을 제공하기 위한 목적으로 설립된 미국의 대표적인 비상장주식거래 플랫폼으로, 일정한 자격을 갖춘 전문투자자를 대상으로 거래시스템을 운영하고 있다. 쉐어스포스트와 NPM은 각각 설립 이후 부터 2018년까지 40억 달러 이상, 170 억 달러 이상의 거래 규모를 기록하며 급격한 성장세를 보인다.3) 이로 인해 미국의 비상장기업은 상장하지 않고도 다양한 경로를 통해 자금을 조달할

2) 금융위원회, “자본시장을 통한 혁신기업의 자금조달체계 개선방안”, 2019년 10월 보도자료.

3) “블록체인을 활용한 비상장기업 주식 거래의 변화”, 코스콤 리포트 Vol. 5, 2019년. 
한국증권학회지 제49권 4호 (2020)

수 있게 되어 성장세를 이어나가고 있다. 이에 따라 2018년 7월 말 기준 전 세계 유니콘 기업의 가치 약 8,400 억 달러 중 $50 \%$ 가량을 미국기업이 차지하고 있는 것으로 나타났으며, 비상장기업 가치에 대한 지표인 SharesPost Private Growth Index는 2015년부터 2018년까지 약 120\% 상승하였다.4)

이러한 미국의 변화에 상응하여 국내에도 비상장주식거래를 위한 플랫폼이 다양하게 등장하고 있다. 한국거래소는 중소기업과 벤처기업 성장을 지원하는 KONEX와 스타트업 기업에 특화한 $\mathrm{KSM}$ 을 운영하고 있다. 금융투자협회는 $\mathrm{K}-\mathrm{OTC}$ 와 $\mathrm{K}-\mathrm{OTC} \mathrm{PRO}$ 를 운영하고 있다. $\mathrm{K}-\mathrm{OTC}$ $\mathrm{PRO}$ 는 미국의 쉐어스포스트와 $\mathrm{NPM}$ 과 같이 전문투자자를 위한 전용 플랫폼을 별도로 설립하고, 통일규격증권 발행 및 예탁 지정 요건 폐지, 정기·수시공시 의무와 증권신고서 제출의무를 면제 등의 혜택을 제공하면서 거래대상 기업의 참여 유인을 높이고 있다.5) 이러한 국내 비상장 주식거래 플랫폼도 미국의 경우와 마찬가지로 최근 급격한 성장세를 보인다. 특히 K-OTC의 경우 2019년 12월에 하루 거래대금 236억 원을 돌파하며 거래 최대치를 달성하여 장외주식에 대한 투자자들의 관심을 보여주었다.6)

비상장주식거래 플랫폼은 일대일 방식으로 이루어지던 비상장주식거래를 중개하는 장을 제공함으로써 비상장주식거래에 대한 접근성을 높였다는 점은 긍정적으로 평가받고 있다. 그러나 절차가 복잡하다는 점과 정보비대칭이 존재하는 등 문제도 있다. 기업으로서는 까다로운 절차를 거쳐야 한다는 점에서 접근성에 일부 제한이 있다. 예를 들어, $\mathrm{K}-\mathrm{OTC}$ 에 등록하기 위해서는 통일주권 발행, 각종 감사요건 등의 기준을 충족해야 하는 등의 절차를 거쳐야 한다. 일반 투자자로서는 쉐어스포스트, NPM, K-OTC PRO 등 전문성의 입증이 필요한 플랫폼이 주를 이룬다는 점에서 접근성이 제한된다. 주주명부 관리 신뢰성 문제와 그로 인한 정보비대칭 문제 또한 일반 투자자의 참여가 제한되는 요인이다. 비상장주식의 상당수가 포함되는 초기 기업은 실물증권을 발행하지 않고 주주명부 역시 기업이 자체적으로 관리하기 때문에, 주주명부가 수기 또는 직원 $\mathrm{PC}$ 에 개별적으로 저장되거나, 주식거래가 이뤄져도 주주명부에 곧바로 반영되지 않는 경우가 많아 일반 투자자가 거래정보를 찾기 힘들다.7) 이로 인해 발생한 정보비대칭은 일반 투자자가 비상장주식거래에 참여할 유인을 감소시킨다.

이와 달리 최근 증권사와 핀테크 업체들이 제시하고 있는 비상장주식거래 플랫폼은 이러한 기존 플랫폼의 문제에 대한 해결책을 제시하고 있다. 모 증권사의 비상장주식전용 중개 플랫폼인 '비상장레이더'는 모바일 트레이딩 시스템에서 비상장주식거래를 중개하며, 국내 장외기업 정보 업체인 '38커뮤니케이션'과 제휴하여 주요 장외기업 정보를 제공한다. 코스콤은 리걸테크(legalTech) 스타트업 기업과 제휴하여 블록체인 기반 장외거래 플랫폼인 '비마이유니콘'을 출시했으며,8)

4) 안유미, “미국 장외유통플랫폼 현황 및 시사점”, 자본시장포커스, 자본시장연구원, 2018-17호, (2018), pp. $1-3$.

5) 금융위원회, “비상장 중소·벤처기업의 중간회수 활성화를 위한 제도 개선방안", 2017년 11월 보도자료.

6) “장외주식도 뜨겁네... K-OTC 하루 거래대금 236억 “역대 최대”, 한국경제, 2019년 12월.

7) “‘낡은” 비상장사 주주명부, 블록체인으로 “새로고침”, 머니투데이, 2019년 5월.

8) “블록체인 장외시장 내달 문 열어... “스타트업 주식 투명하게 거래”, 한국경제, 2019년 10월. 
Impact of Private Equity Trading Platforms on Firm Value and Corporate Governance

모 핀테크 업체는 삼성증권 및 딥서치와 협업하여 ‘증권플러스 비상장’을 출시하였다.9) 해당 플랫폼들은 주주명부와 기업정보 등 최소한의 서류만 제출하도록 하여 등록 요건을 완화하였으며, 블록체인 기술을 통해 주주명부를 관리해주어 신뢰성 또한 높인다. 이처럼 최근 증권사와 핀테크 업체들이 공개한 비상장주식거래 플랫폼은 기존 장외주식의 거래플랫폼보다 진입장벽을 획기적으로 낮추고 투명성을 강화함으로써 비전문적인 투자자들의 유입도 더욱 증가할 것으로 보인다. 아래 <표 $1>$ 은 이러한 비상장주식거래 플랫폼의 주요 특징을 정리한 것이다.

〈표 1〉 증권사 및 핀테크 업체의 비상장주식거래 플랫폼

다음 표는 “증권업계, ‘레몬마켓을 잡아라'... 비상장주식 시장 겨낭 플랫폼 '봇물”, 뉴스웨이, 2019년 10월 기사의 그림을 재구성한 것으로, 2018 년 유안타증권의 비상장레이더를 시작으로 증권사 및 핀테크 업체에서 공개 및 운영 중인 비상장주식거래 플랫폼의 운영주체와 특징을 정리한 것이다.

\begin{tabular}{|c|c|c|c|}
\hline & 비상장레이더 & 비마이유니콘 & 증권플러스 비상장 \\
\hline 운영 & 유안타증권 & $\begin{array}{l}\text { 코스콤, KEB하나은행, } \\
\text { 하나금융투자, } \\
\text { 한국액셀러레이터협회 등 }\end{array}$ & 두나무, 삼성증권, 딥서치 \\
\hline 특징 & $\begin{array}{l}\text { - 비상장 주식 매매 중개 } \\
\text { - 비상장 주요 종목의 제무 } \\
\text { 제표, 기준가격, IPO 관련 } \\
\text { 정보 제공 } \\
\text { - 기존 유안타증권 플랫폼 } \\
\text { 내에서 제공 }\end{array}$ & $\begin{array}{l}\text { - 주주명부를 블록체인으로 } \\
\text { 관리 } \\
\text { - 에스크로 안전결제 } \\
\text { - 엑셀러레이터협회와 } \\
\text { 협업으로 기업유치, } \\
\text { 투자정보 제공 }\end{array}$ & $\begin{array}{l}\text { - 주주명부를 블록체인으로 관리 } \\
\text { - 에스크로 안전결제 } \\
\text { - 통일주권 발행 비상장기업 거래 } \\
\text { 가능 } \\
\text { - 추후 비통일 주권 종목으로 확대 } \\
\text { 예정 }\end{array}$ \\
\hline
\end{tabular}

세 플랫폼은 모바일 애플리케이션 기반으로 접근성과 편리성을 개선하였다는 특징을 갖는다. 그러나 기존 모바일 플랫폼에 비상장주식의 매매 서비스를 추가한 비상장레이더와 달리, 비마이유니콘과 증권플러스 비상장은 블록체인을 활용한 새로운 형태의 서비스를 제시한다. 이는 접근성에 더하여 정보의 투명성을 확보한다. 비상장레이더 또한 주요 비상장주식 종목에 대한 핵심적인 정보를 제공하는 서비스를 보유하고 있지만, 블록체인 기술을 활용한 다른 두 플랫폼이 투명성 측면에서는 우위에 있는 것으로 보인다. 증권플러스 비상장의 경우 블록체인 기술을 도입하겠다는 계획을 발표한 이후 블록체인 기술의 구체적인 활용은 제시하지 못하지만, 비마이유니콘은 블록체인 네트워크의 활용방안을 제시한다. 아래의 <그림 $1>$ 은 비마이유니콘 에서 제시한 플랫폼의 거래구조를 보여준다. 코스콤을 중심으로 관련 정보를 제공하는 다양한 기업들이 블록체인 네트워크를 형성하고 내부적으로 정보를 공유한다. 매수인은 공유된 정보에 접근하여 매도인의 주권 보유 여부를 확인할 수 있다. 주주명부는 계약이 체결됨과 동시에 자동으로 기업에 승인요청을 보내고, 기업이 승인하면 블록체인 네트워크에 새로운 주주명부가 기록된다. 이는 블록체인 기술을 코인 및 토큰 발행이 아닌 주식거래에 활용했다는 점에서 블록체인 업계에서 긍정적으로 평가받고 있다.

9) “코스콤 vs. 두나무 ‘비상장 주식, 블록체인으로 안전거래”, 팍스넷뉴스, 2020년 1월. 


\section{〈그림 1〉비마이유니콘의 거래방식}

다음 그림은 코스콤에서 제시한 비마이유니콘의 거래방식을 재구성한 것이다. 운영주체인 다수의 기업이 내부적으로 관련정보를 공유하는 블록체인 네트워크를 구축하고, 이를 활용하여 매수인과 매도인, 거래대상 기업을 중개하는 형태이다.
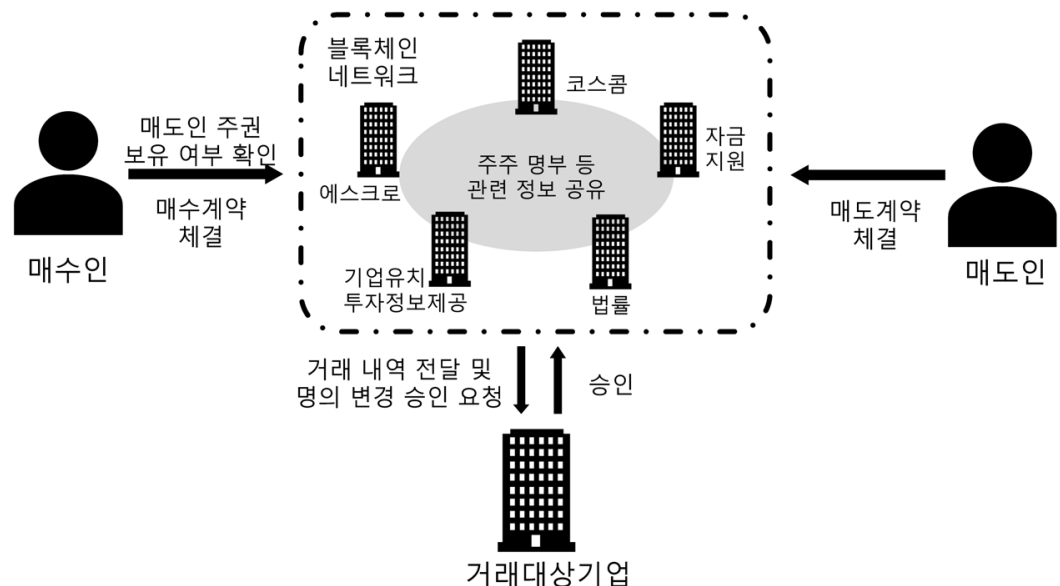

이러한 변화는 전문성을 갖춘 기관투자자(institutional investor)에 의해 주도되던 비상장주식 거래에 다수의 소매투자자(retail investor)가 참여할 수 있게 한다. 기관투자자는 소매투자자보다 우월한 인적, 물적 자원을 바탕으로 정보에 기반을 둔 전문적인 투자를 진행한다(Lee, 2016). 반면, 소매투자자는 직관에 의존하여 불규칙한 투자 양상을 보인다. 이는 비상장주식거래 플랫폼이 활성화됨으로써 비상장주식에 투자하는 소매투자자가 증가하게 되면 이전보다 비상장주식거래의 유동성이 더욱 증가할 것임을 의미한다.

\section{2 비상장주식거래 플랫폼 활성화의 기대효과}

본 절에서는 비상장주식과 관련된 기존의 논의를 검토하고, 비상장주식거래 플랫폼이 기업 가치와 지배구조에 미치는 영향을 살펴본다. 비상장주식거래를 직접적인 연구대상으로 다룬 논문이 일부 존재한다. Eom et al.(2009)은 금융투자협회의 $\mathrm{K}-\mathrm{OTC}$ 의 전신인 프리보드에 대한 분석을 제시하며, 프리보드가 한국의 장외주식시장으로 제대로 기능하지 못하고 있음을 비판하였다. Choi and Lee(2019)는 중소기업 주식 거래소가 중소기업에 성장 기회를 제공하는 등 기업 가치에 긍정적인 역할을 할 수 있다는 결론을 제시했다. 그러나 분석 대상을 비상장주식 거래로 명시한 연구는 아직 활발히 진행되지 않고 있다.

비상장주식거래 플랫폼은 비상장 중소기업의 자금조달 경로를 다양화하여 중소기업의 자금조달 문제를 해결하고, 지배구조 개선에도 긍정적인 영향을 미칠 것으로 보인다. 중소기업벤처부가 2018년 실시한 벤처기업 정밀실태조사에 따르면 중소벤처기업 경영 애로사항 중 약 $75 \%$ 가 '자금조달 운용 등 관리' 항목이 차지하고 있을 정도로, 중소기업의 자금조달 문제가 심각하다.10)

10) “중기 전문 투자회사, 유니콘 기업 제대로 길러내려면”, 비즈니스워치, 2019년 5월. 
Impact of Private Equity Trading Platforms on Firm Value and Corporate Governance

기존에는 비상장 중소기업은 자본시장에서 자금을 끌어오기보다는 은행 대출을 통해 자본을 조달하였다. 그러나 은행 대출은 여러 심사 과정을 통해 보수적으로 이뤄진다는 문제가 있다. 기업 가치가 상대적으로 높은 유니콘 기업 또한 자본제약의 문제에서 벗어날 수 없다. 특히 국내 유니콘 기업의 경우 국외 투자자 의존도가 높게 나타나는데, 이는 국내 민간 자본시장이 상장사 중심으로 이루어져 있어 충분히 활성화되지 못했기 때문으로 보인다.11) 반면, 최근 나타나는 비상장주식거래 플랫폼은 상장사 중심의 국내 자본시장 운영을 비상장사로 확대하여 국내 중소기업들의 자본제약 문제를 해소해줄 것으로 보인다.

주식거래의 유동성 개선이 기업 가치와 지배구조에 긍정적인 영향을 미친다는 연구가 다수 존재한다는 점을 고려할 때, 비상장주식거래 플랫폼의 도입은 비상장 중소기업에 긍정적인 영향을 미친다고 볼 수 있다. 비상장주식거래 플랫폼이 관련 주식의 거래에 대한 투자자들의 접근성을 높임으로써 거래 유동성을 높일 것으로 기대되기 때문이다. Park and Eom(2008)은 유동성이 기대주식수익률을 유의미하게 설명한다는 것을 실증적으로 보였으며, Fang et al. (2009)는 유동성이 높은 기업이 그렇지 않은 기업보다 기업 성과가 우월함을 보였다. 이 외에도 유동성이 기업의 수익성과 기업 가치와 양(+)의 상관관계를 갖는다는 점을 실증적으로 입증한 논문들이 존재한다(Borisova et al., 2013; Cheung et al., 2015). 유동성과 기업지배구조의 관계를 밝힌 논문들도 존재한다. $\operatorname{Maug(1998)ㅇㅡㄴ~ㄷㅐㄹㅑㅇㅈㅣㅂㅜㄴㅇㅢ~ㅋㅡㄱㅣ(block~size)ㄱㅏ~ㄴㅐㅅㅐㅇㅈㅓㄱㅇㅡㄹㅗ~}$ 결정될 경우, 유동성이 대량지분의 형성을 쉽게 만들어 지배구조를 긍정적으로 개선한다는 점을 제시한다. Edmans(2009) 또한, 대량지분의 크기가 내생적인 상황을 가정했을 때, 주요 대주주(blockholder)가 기업 가치를 모니터링(monitoring)하는 과정에서 유동성이 높을수록 경영자(manager)에 의한 기업 가치의 하락을 더 정확하게 파악할 수 있다는 점을 보인다. 이를 바탕으로 Edmans는 주요 대주주가 경영에 관여하지 않더라도 경영자의 근시안적 행동을 약화시키고 장기적인 투자를 유도할 수 있어 대리인 문제의 대안이 될 수 있다고 주장한다. Bharath et al.(2013)과 Gerken(2014)의 연구는 Maug(1998)와 Edmans(2009)의 이론연구를 실증적으로 뒷받침한다. Gerken(2014)은 도구변수 추정법을 통해 유동성이 대량지분 형성과 양(+)의 상관관계가 있음을 실증적으로 보였으며, Bharath et al.(2013)은 유동성이 높을 경우, 대량지분투자자의 규모가 대리인비용을 낮출 수 있음을 실증적으로 보였다. Alvarez et al (2018)도 이와 유사한 연구결과를 통해 주요 대주주가 존재할 경우 유동성이 기업에 긍정적인 영향을 미칠 수 있음을 보인 바 있다.

본 논문은 이와 같은 논의를 비상장기업에 초점을 맞춰 진행한다. 이를 위해 본 논문에서는 비상장기업의 대표적인 형태로 가족기업을 가정한다.12) 국내외 기업의 상당수가 가족기업의 형태를 띠며, 국내 비상장기업의 경우 그 비중이 특히 더 높다(Park, 2016). 이러한 점에서

11) “배달의민족처럼... 유니콘기업 $90 \%$ 국외자본이 키웠다”, 한겨레, 2020년 1월.

12) 본 논문에서의 가족기업은 창업주와 지배대주주, 그리고 경영자가 일치하는 형태의 기업을 말한다. 가족기업은 일반적으로 창업주 일가가 경영 전반에 개입하는 형태를 의미하는데, 본 논문에서는 이 중 대주주와 경영자가 일치한다는 특징에 초점을 맞춘다. 이러한 정의는 비상장기업 대부분이 초기회사이기 때문에 창업주, 지배대주주, 경영자가 일치한다는 점에서 본 논문이 분석하고자 하는 상황에 부합한다. 
한국증권학회지 제49권 4호 (2020)

비상장주식거래 플랫폼의 효과에 대한 분석을 위해서는 기업의 형태를 가족기업으로 단순화하여 논의를 진행하는 것이 가능하다. 가족기업에 관한 기존의 논의는 다음과 같다. Pindado et al.(2011)은 가족지배가 기업의 투자현금흐름 민감도를 감소시킴을 보임으로써, 가족지배가 투자의 비효율성을 완화한다는 것을 보였다. Villalonga and Amit(2006)는 전문경영자의 비효율적인 경영으로 기업의 성과나 가치가 하락한다면 지배주주 가족이 이를 극복하기 위해 직접 경영을 맡을 수 있으며, 대체로 가족기업의 설립자가 $\mathrm{CEO}$ 일 때 기업 가치가 높다는 결과를 보여주었다. 이와 반대로 $\operatorname{Kang}(2014)$ 은 지배주주 가족이 임원에 포함되지 않는 경우가 기업 가치가 높음을 제시하며, 전문경영인 체제가 가족경영보다 효과적임을 주장했다. Kang(2014)은 이러한 현상의 원인으로 가족에 의한 소유와 경영의 일치가 그룹에 대한 통제권 유지에 몰입하게 하여 발생한다고 보았다. 본 논문은 유동성과 기업 가치의 상관관계에 대한 분석을 대주주와 경영자가 일치하는 가족기업의 형태를 가정하여 진행한다. 경영자인 대주주는 투자에 대한 의사결정과 주식거래에 대한 의사결정을 모두 진행한다는 점에서 전문경영인을 고용하는 경우와 구분된다. 특히, 장기적인 투자의사결정이 실질적인 기업 가치에 영향을 미친다는 점에 착안하여, 비상장주식거래 플랫폼의 활성화로 인한 유동성 증가가 비상장기업의 투자의사결정에 미치는 영향을 분석한다.

\section{3. 모형의 설계와 분석}

\section{1 모형설계}

본 절에서는 비상장주식거래 플랫폼의 도입이 비상장기업의 자본투자에 미치는 영향을 $\mathrm{Kyle}(1985)$ 의 시장미시구조 모형을 바탕으로 설명한다. 중개 플랫폼이 존재하지 않을 경우, 비상장주식의 거래는 접근성이 낮아 외부의 유동성 거래자(liquidity trader)의 참여가 부족하다. 그러나 플랫폼의 도입은 유동성 거래자의 참여를 높여 비상장주식거래의 유동성을 개선할 것으로 보인다. 따라서 이러한 비상장주식거래의 유동성이 개선되었을 때, 기업의 자본투자에 관한 의사결정이 어떻게 변화하는지를 살펴본다.

비상장기업의 경우, 대주주와 경영자가 일치하는 가족기업의 형태로 경영되는 경우가 대부분 이다. 대주주는 기존 시장미시구조 모형의 정보거래자(informed trader)와 마찬가지로 내부 정보를 통해 미래 주식가격의 변화를 통해 이익을 얻는다. 대주주가 경영에 개입할 가능성은 존재하지만, 실질적으로 회사를 경영하는 것은 경영자이며, 장기적인 관점에서 기업 가치를 상승시키기 위한 투자에 대한 의사결정을 하는 주체 또한 경영자이다. 이는 경영자가 주주의 이익에 반하여 개인의 이익을 추구하게 되는 대리인 문제를 일으킨다. 이러한 문제는 대주주가 경영하는 가족기업에서도 발생할 가능성이 있다. Ashraf et al.(2020)은 가족기업에서도 경영을 주도하는 가족구성원이 사적 이익을 추구할 경우, 외부 주주들의 지지가 감소하는 이중 대리인 문제(dual agency problem)가 나타날 수 있다고 지적한다. 이에 따라 본 논문에서는 가족기업 에서의 이중 대리인 문제를 투자수준을 고려하여 정의하고, 비상장주식거래 플랫폼 도입을 통한 일반 투자자의 참여가 이중 대리인 문제를 감소시킬 수 있음을 보인다. 
Impact of Private Equity Trading Platforms on Firm Value and Corporate Governance

이를 반영하여 본 논문은 비상장주식 유통시장에 대한 이론모형을 다음과 같이 구성한다.13) 우선 의사결정의 주체는 경영자와 외부 주주, 유동성 거래자, 시장조성자(market maker)이다. 경영자는 기존 모형에서의 대주주와 경영자의 의사결정을 포괄하는 주체로, 미래 주가 흐름에 대한 정보에 기반을 두고 의사를 결정한다. 경영자는 자신의 기대이윤을 극대화하는 주식거래량 $x_{m}$ 과 투자수준 $i$ 을 결정한다. 외부 주주는 총 $N$ 명 존재하며, 미래 주가 흐름에 대한 정보에 기반을 두고 자신의 이윤을 극대화하는 주식거래량 $x_{k} k=1, \ldots, N$ 을 결정한다. 그러나 경영에 직접 개입하지 않기 때문에 투자수준을 결정하지는 않는다. 유동성 거래자는 기존의 시장미시구조 모형에서와 마찬가지로 주가의 변화와 무관하게 주식을 거래한다. 이들의 거래량 $z$ 는 평균이 0 이고 분산이 $\sigma_{z}^{2}$ 인 정규분포를 따른다고 가정한다. 시장조성자는 Kyle(1985)의 논문과 마찬가지로 시장 가격 $p$ 를 결정한다. 시장조성자는 거래량 $w=x_{m}+x_{1}+\ldots+x_{N}+z$ 을 관찰하고, 이를 바탕으로 미래주가의 조건부 기댓값을 $p$ 로 결정한다. 이 때, 유동성 거래자는 총거래량 $w$ 만 관찰할 수 있고, 경영자와 유동성 거래자가 제시한 각각의 거래량을 분리하여 관찰할 수는 없다.

이들의 의사결정은 0 기부터 2 기까지에 걸쳐 이루어진다. 0 기는 기업이 장기적 투자를 결정하는 기간이다. 본 모형에서 장기란 0 기에서 2 기까지의 총 기간을 의미하며, 단기란 0 기에서 1 기까지의 기간을 의미한다. 본 논문에서는 장기적 투자를 단기적으로 기업 가치를 하락시키지만, 장기적으로는 기업 가치를 상승시키는 투자라고 정의한다.14) 1 기는 주식거래가 이루어지는 기간으로, 2 기의 기업 가치 변화에 대한 신호가 경영자에게 주어진다. 2 기에는 신호에 따라 실제로 기업 가치가 변한다.

경영자의 투자의사 결정이 이루어지는 0기에는 기업의 가치가 $F_{0}$ 이며, 경영자는 미래의 상황을 고려하여 투자수준 $i$ 를 결정한다. 기업은 투자에 성공하면 그로 인한 보수(payoff)로 기업 가치가 $I(>i)$ 만큼 상승한다. 기업이 0기에 투자를 할 경우, 2 기에 확률 $q(i)$ 로 기업 가치가 상승하며, $1-q(i)$ 의 확률로 상승하지 않는다. 투자로 인해 기업 가치가 상승하게 되는 확률 $q(i)$ 는 투자수준 $i$ 에 의해 결정되며, 오목하게 증가하는 형태를 가정한다 $\left(q^{\prime}>0, q^{\prime \prime}<0, q \in[0,1]\right)$. 이는 경영자가 0 기에 투자수준을 결정함에 따라 투자결과의 확률분포가 달라진다는 것을 의미한다. 경영자가 투자수준을 높일수록 투자의 성공에 대한 불확실성이 줄어드는 것이다.15) 기업의 가치는 투자수준 $i$ 만큼 하락하여, 1 기의 기업 가치는 $F_{1}=F_{0}-i$ 라고 알려진다. 그러나 유동성 거래자와 시장조성자는 투자에 관한 정보를 갖고 있지 않다고 가정한다. 즉, 이들은 1 기와 2 기의 기업 가치 변화가

13) 일반 투자자의 경우, 거래 규모가 큰 발행시장에 참가하기 힘들다. 따라서 일반 투자자 유입에 따른 변화를 분석하는 본 논문에서는 유통시장에 대해서만 다룬다.

14) 장기적 투자는 기업 가치에 영향을 미치지 않고 단기적인 매출 상승만을 유도하는 근시안적 투자와 대비되는 개념이라고 할 수 있다.

15) 성공확률뿐만 아니라 투자 성공에 따른 보수인 $I$ 까지 투자수준 $i$ 의 증가함수로 가정할 수도 있으나, 외부 주주가 투자수준에 따른 보수의 분포를 안다고 가정하는 한 결과에는 큰 영향을 미치지 않는다. 본 논문에서는 직관적인 해석을 위해 투자로 인한 보수를 위와 같이 단순화하였다. 
한국증권학회지 제49권 4호 (2020)

투자에 의한 것임을 알지 못한다.16) 반면, 외부 주주는 단기적인 기업 가치 하락이 투자로 인한 것임을 인지하며, 투자수준에 따른 보수의 확률분포까지 알고 있다고 가정한다.

1 기에는 주식거래가 이루어지며, 경영자는 자신에게 주어진 2 기의 기업 가치 변화에 대한 신호를 바탕으로 기대이윤이 극대화되는 거래량 $x$ 만큼 주식을 거래한다. 1 기의 경영자는 2 기에 발생할 주식가격 변동에 대한 신호 $\tilde{\epsilon}$ 을 받는다. 경영자는 해당 신호를 두 가지의 상반된 신호로 분리하여 받게 된다 $(\tilde{\epsilon}=\tilde{\delta}+\tilde{\nu})$. 하나는 투자로 인한 2 기의 기업 가치 상승에 관한 신호 $\tilde{\nu}$ 이다. $\tilde{\nu}$ 는 확률 $q(i)$ 로 $I$ 의 값을, 확률 $1-q(i)$ 로 0 의 값을 갖는 확률변수이다. 다른 하나는 불규칙한 미래의 기업 가치 변동에 대한 신호 $\tilde{\delta}$ 로, 이 신호는 평균이 0 이고, 분산이 $\sigma_{F}^{2}$ 인 정규분포를 따른다고 가정한다. 외부 주주는 경영자와 마찬가지로 $\tilde{\delta}=\delta$ 의 신호를 받지만, 1 기에서도 $\tilde{\nu}$ 는 알 수 없다고 가정한다. 시장조성자는 투자에 관한 정보를 전혀 알 수 없으므로, 기업 가치의 변화가 불규칙한 변화에 의한 것으로만 인지한다. 따라서 시장조성자는 2 기의 주가변동 $\tilde{\epsilon}$ 을 평균이 0이고 분산이 $\sigma_{F}^{2}$ 인 정규분포를 따르는 확률변수로 판단하고 가격을 결정한다.

경영자와 외부 주주는 각각 $s_{m}$ 과 $s_{k}, k=1, \ldots, N$ 의 지분을 보유하고 있으며, 경영자는 경영권 확보를 위해 다른 대주주보다 높은 지분을 확보하여 $s_{m}>s_{k}$ 의 상태를 유지한다. 이는 가족기업의 경우, 지분율의 결정에서 큰 영향을 미치는 것은 기업 가치나 투자수익보다는 해당 기업에 대한 통제권인 특징이 나타난다는 점을 반영한다(Kang and Park, 2011; Kang et al., 2006).

\section{2 모형 분석}

본 절에서는 앞서 설계한 모형에 대한 분석을 진행한다. 총 2 기간 중 참여 주체의 의사결정이 이루어지는 기간은 0 기와 1 기이며, 0 기에서 경영자의 의사결정은 1 기의 상황에 기반을 두고 이루어진다. 따라서 1 기의 시장 균형을 도출한 후, 0 기에서의 경영자의 투자의사 결정을 분석한다.

\subsection{1 주식거래 분석}

먼저 1 기의 상황을 분석하면 다음과 같다. 경영자는 0 기에서 결정한 투자수준 $i$ 와 2 기의 주가변동에 대한 신호가 $\tilde{\delta}=\delta, \tilde{\nu}=\nu$ 로 주어졌을 때, 자신의 기대이윤을 극대화하는 거래량을 결정한다. 따라서 경영자의 거래량 $x_{m}$ 은 식 (1)과 같이 정리할 수 있다.

$$
x_{m}(\delta, \nu)=\arg { }_{x_{m}}^{\max } E\left[\pi_{m} \mid \delta, \nu\right]=E\left[x_{m}\left(F_{2}-p\right) \mid \delta, \nu\right]
$$

반면, 외부 주주는 $\tilde{\delta}=\delta$ 의 신호만을 받기 때문에, 이를 바탕으로 자신의 기대이윤을 극대화하는 거래량을 결정한다. 따라서 외부 주주의 거래량 $x_{k}$ 는 식 (2)와 같다.

16) 이러한 가정은 $\operatorname{Edmans(2009)ㅇㅢ~ㅇㅕㄴㄱㅜㄹㅡㄹ~ㅊㅏㅁㄱㅗㅎㅏㅇㅕㅆㄷㅏ.~ㄷㅏㄴ,~} \operatorname{Edmans}(2009)$ 의 연구에서는 경영자와 주요 대주주가 분리되어 있어 주요 대주주 또한 투자에 관한 의사결정을 알지 못한다고 가정하였으나, 본 연구에서는 경영자가 주식거래에 참여하면서도 투자로 인한 변화도 인지한다. 
Impact of Private Equity Trading Platforms on Firm Value and Corporate Governance

$$
x_{k}(\delta)=\arg \underset{x_{k}}{\max } E\left[\pi_{k} \mid \delta\right]=E\left[x_{k}\left(F_{2}-p\right) \mid \delta\right]
$$

시장조성자는 시장 총거래량인 $w$ 가 주어졌을 때, 2 기의 주가인 $F_{2}$ 의 조건부 기댓값을 가격으로 설정한다. 식 (3)은 이를 나타낸다. 시장조성자는 투자와 관련된 정보는 알 수 없으므로 $F_{2}=F_{1}+$ $\tilde{\epsilon}, \tilde{\epsilon} \sim N\left(0, \sigma_{F}^{2}\right)$ 라고 인지한다.

$$
p(w)=E\left[F_{2}=F_{1}+\tilde{\epsilon} \mid w=x_{m}+x_{1}+\ldots+x_{N}+z\right]
$$

Proposition 1. 경영자와 외부 주주의 거래량이 각각 식 (1)과 식 (2)에 의해서 결정되고, 시장조성자가 식 (3)에 따라 가격을 결정할 때, 주식거래량 $x_{m}, x_{k}$ 와 가격 $p$ 는 식 (4)와 같이 선형함수의 형태로 나타나는 균형이 존재한다.

$$
\begin{aligned}
& x_{m}(\delta, \nu)=\beta\left(\delta+\nu+\frac{N}{2}(\nu-q(i) I)\right), \\
& x_{k}(\delta)=\beta(\delta+q(i) I), \text { for } k=1, \ldots, N, \\
& p(w)=F_{1}+\lambda w, \\
& \text { where } \beta=\frac{\sigma_{z}}{\sigma_{F} \sqrt{N+1}}, \lambda=\frac{\sqrt{N+1} \sigma_{F}}{(N+2) \sigma_{z}}, w=x_{1}+\sum_{k=1}^{N} x_{k}+z
\end{aligned}
$$

Proof: 가격과 거래량이 다음 식 (5)와 같이 선형으로 이루어져 있다고 가정한다.

$$
x_{m}(\delta, \nu)=a_{1}+a_{2} \delta+a_{3} \nu, x_{k}(\delta)=b_{1}+b_{2} \delta, p(w)=\mu+\lambda w
$$

시장조성자는 투자에 관한 정보를 알지 못하므로 시장 가격이 $w \sim N\left(0,\left(a_{2}+b_{2}\right)^{2} \sigma_{F}^{2}+\sigma_{Z}^{2}\right)$ 의 분포를 갖는다고 인지한다. 따라서 가격은 다음 식 (6)과 같다.

$$
p(w)=\mu+\lambda w=E\left[F_{2}=F_{1}+\tilde{\epsilon} \mid w\right]=F_{1}+E[\tilde{\epsilon} \mid w]
$$

$w$ 가 정규분포를 따르기 때문에 $E[\tilde{\epsilon} \mid w]$ 는 식 (7)과 같다. 따라서 $\mu$ 와 $\lambda$ 는 식 (8)과 같다.

$$
\begin{gathered}
E[\tilde{\epsilon} \mid w]=\frac{\left(a_{2}+b_{2}\right) \sigma_{F}^{2}}{\left(a_{2}+b_{2}\right)^{2} \sigma_{F}^{2}+\sigma_{z}^{2}} w \\
\mu=F_{1}, \quad \lambda=\frac{\left(a_{2}+b_{2}\right) \sigma_{F}^{2}}{\left(a_{2}+b_{2}\right)^{2} \sigma_{F}^{2}+\sigma_{z}^{2}}
\end{gathered}
$$

경영자는 식 $(9)$ 의 기대이윤극대화문제를 풀어 거래량 $x_{m}$ 을 결정한다.

$$
\max _{x_{m}} E\left[\pi_{m} \mid \delta, \nu\right]=E\left[x_{m}\left(F_{2}-p\right) \mid \delta, \nu\right]
$$


한국증권학회지 제49권 4호 (2020)

$$
\begin{aligned}
& =E\left[x_{m}(\delta+\nu)-\lambda x_{m}-\lambda N\left(b_{1}+b_{2} \delta\right)-\lambda z \mid \delta, \nu\right] \\
& =x_{m}(\delta+\nu)-\lambda x_{m}-\lambda N\left(b_{1}+b_{2} \delta\right)
\end{aligned}
$$

식 (9)에 대한 1계 조건(first-order condition)을 정리하면 식 (10)과 같으며, 이에 따라 경영자의 거래량은 식 (11)과 같다.

$$
\begin{aligned}
& \text { F.O.C. }: \frac{\partial E\left[\pi_{m} \mid \delta, \nu\right]}{\partial x_{m}}=\delta+\nu-2 \lambda x_{m}-\lambda N b_{1}-\lambda N b_{2} \delta=0 \\
& x_{m}^{*}(\delta, \nu)=a_{1}+a_{2} \delta+a_{3} \nu=-\frac{1}{2} N \alpha+\frac{1-\lambda N \beta}{2 \lambda} \delta+\frac{1}{2 \lambda} \nu
\end{aligned}
$$

외부 주주는 식 (12)의 기대이윤극대화문제를 풀어 거래량 $x_{k}$ 을 결정한다.

$$
\begin{aligned}
\max _{x_{k}} E\left[\pi_{k} \mid \delta\right] & =E\left[x_{k}\left(F_{2}-p\right) \mid \delta\right] \\
& =E\left[x_{k}(\delta+\tilde{\nu})-\lambda x_{k}-\lambda\left(a_{1}+a_{2} \delta+a_{3} \tilde{\nu}\right)-\lambda(N-1)\left(b_{1}+b_{2} \delta\right)-\lambda z \mid \delta\right] \\
& =x_{k}(\delta+q(i) I)-\lambda x_{k}-\lambda\left(a_{1}+a_{2} \delta+a_{3} q(i) I\right)-\lambda(N-1)\left(b_{1}+b_{2} \delta\right)
\end{aligned}
$$

식 (13)은 식 (12)에 대한 1계 조건을 정리한 것이며, 이에 따라 식 (14)와 같이 외부 주주의 거래량이 결정된다.

$$
\begin{aligned}
& \text { F.O.C. } \frac{\partial E\left[\pi_{k} \mid \delta\right]}{\partial x_{k}}=\delta+q(i) I-2 \lambda x_{k}-\lambda a_{1}-\lambda a_{2} \delta-\lambda b_{3} q(i) I-\lambda(N-1) b_{1}-\lambda(N-1) b_{2} \delta=0 \\
& x_{k}^{*}(\delta)=b_{1}+b_{2} \delta=-\frac{1}{2 a}+\frac{1-\lambda b_{3}}{2 \lambda} q(i) I-\frac{N-1}{2} b_{1}+\frac{1-\lambda a_{2}-\lambda(N-1) b_{2}}{2 \lambda} \delta
\end{aligned}
$$

식 (8)과 식 (11), 식 (14)를 연계하여 정리하면 식 (4)가 도출됨을 확인할 수 있다.

\subsection{2 자본투자 의사결정 분석}

경영자는 1 기의 균형을 고려하여 0 기에 투자수준 $i$ 를 결정한다. 0 기의 경우 1 기와는 달리 2 기의 기업 가치에 대한 신호를 받을 수 없으므로 신호가 확률변수임을 고려하여 기대이윤을 계산한다. 또한, 투자로 인한 자신 지분의 가치변화까지 고려한다. 이에 따라 기대이윤을 정리하면 식 (15)와 같다.

$$
\begin{aligned}
E\left[\pi_{m, 0}\right] & =E\left[x\left(\widetilde{F}_{2}-p\right)+s_{m}\left(\widetilde{F}_{2}-F_{0}\right)\right] \\
& =\frac{\sigma_{z}}{\sigma_{F} \sqrt{N+1}}\left(\frac{1}{N+2} \sigma_{F}^{2}+\frac{N+2}{4} q(i) I^{2}+\left(\frac{1}{N+2}-\frac{N+2}{4}\right) q(i)^{2} I^{2}\right)+s_{m}(q(i) I-i)
\end{aligned}
$$

경영자는 식 (15)를 최대화하는 투자수준을 결정한다. 경영자에게 최적인 투자수준 $i_{m}$ 은 식 (16)의 1계 조건을 만족한다. 
Impact of Private Equity Trading Platforms on Firm Value and Corporate Governance

$$
\frac{\partial E\left[\pi_{m, 0}\right]}{\partial i}=\frac{\sigma_{z}}{\sigma_{F} \sqrt{N+1}}\left(\frac{N+2}{4} q^{\prime}(i) I^{2}+\left(\frac{1}{N+2}-\frac{N+2}{4}\right) 2 q^{\prime}(i) q(i) I^{2}\right)+s_{m}\left(q^{\prime}(i) I-1\right)=0
$$

그러나 이는 외부 주주의 이윤을 고려하지 않은 것이다. 경영자와 외부 주주를 포함한 모든 주주의 이익을 극대화하는 투자수준을 $i_{a l l}$ 이라고 할 때, $i_{a l l}$ 은 식 (17)의 기대이윤을 극대화하는 식을 풀어 식 (18)의 1 계 조건을 만족하는 수준으로 결정된다.

$$
\begin{aligned}
& \begin{aligned}
E\left[\pi_{\text {all }, 0}\right] & =E\left[\pi_{m, 0}\right]+E\left[N x_{k}\left(\widetilde{F}_{2}-p\right)+\sum_{k=1}^{N} s_{k}\left(\widetilde{F}_{2}-F_{0}\right)\right] \\
& =E\left[\pi_{m, 0}\right]+\frac{N \sigma_{z}}{\sigma_{F} \sqrt{N+1}}\left(\frac{1}{N+2} \sigma_{F}^{2}+\frac{1}{N+2} q(i)^{2} I^{2}\right)+\sum_{k=1}^{N} s_{k}(q(i) I-i) \\
\frac{\partial E\left[\pi_{\text {all }, 0}\right]}{\partial i} & =\frac{\partial E\left[\pi_{m, 0}\right]}{\partial i}+\frac{N \sigma_{z}}{\sigma_{F} \sqrt{N+1}} \frac{1}{N+2} 2 q^{\prime}(i) q(i) I^{2}+\sum_{k=1}^{N} s_{k}\left(q^{\prime}(i) I-1\right)=0
\end{aligned}
\end{aligned}
$$

Proposition 2. $i_{m}$ 과 $i_{\text {all }}$ 이 각각 식 (16)과 식 (17)을 만족하는 수준으로 결정될 때, 항상 $i_{m}<i_{\text {all }}$ 이 성립한다.

Proof: 식 (17)의 최적화 문제에서 2계 조건(second-order condition)이 만족한다면, 식 (18)에서 투자수준 $i$ 에 대한 감소함수 $g(i)=\frac{\partial E\left[\pi_{a l l, 0}\right]}{\partial i}$ 를 정의할 수 있다. $g(i)$ 에 $i_{m}$ 을 대입했을 때, 좌변이 음의 값일 경우 $i_{m}>i_{a l l}$, 양의 값일 경우 $i_{m}<i_{a l l}$ 가 성립한다. 식 (16)을 만족하는 $i_{m}$ 를 식 (18)의 좌변에 대입하여 정리하면 식 (19)와 같다. 식 (19)에서 $q\left(i_{m}\right)>1 / 2$ 임을 가정한다. 이러한 가정은 투자의 기대이윤이 0 인 투자수준에서 투자성공확률이 $1 / 2$ 보다 큰 경우 성립한다. $q^{\prime}(i) I-1=0$ 인 투자수준을 $i^{*}$ 이라고 할 때, $q\left(i^{*}\right)>1 / 2$ 일 경우, $i^{*}$ 를 식 $(16)$ 에 대입하면 $i^{*}<i_{m}$ 이 성립함을 알 수 있다. 이에 따라 $1 / 2<q\left(i^{*}\right)<q\left(i_{m}\right)$ 이 성립한다.

$$
\begin{aligned}
g\left(i_{m}\right) & =\frac{N \sigma_{z}}{\sigma_{F} \sqrt{N+1}} \frac{2}{N+2} q^{\prime}\left(i_{m}\right) q\left(i_{m}\right) I^{2}+\sum_{k=1}^{N} s_{k}\left(q^{\prime}\left(i_{m}\right) I-1\right) \\
& >N\left(\frac{\sigma_{z}}{\sigma_{F} \sqrt{N+1}} \frac{2}{N+2} q^{\prime}\left(i_{m}\right) q\left(i_{m}\right) I^{2}+s_{m}\left(q^{\prime}\left(i_{m}\right) I-1\right)\right) \\
& =\frac{N \sigma_{z}}{\sigma_{F} \sqrt{N+1}} \frac{N+2}{4}\left(q^{\prime}\left(i_{m}\right) I^{2}-2 q\left(i_{m}\right) q^{\prime}\left(i_{m}\right) I^{2}\right)>0
\end{aligned}
$$

따라서 $g\left(i_{m}\right)$ 가 항상 양의 값을 가지므로, 항상 $i_{m}<i_{a l l}$ 의 관계가 성립하는 상황이라는 것을 확인할 수 있다.

이는 경영자가 주주 전체의 이익을 극대화하는 투자수준보다 낮은 수준으로 투자를 하고 있음을 보여주므로, 이중 대리인 문제가 발생함을 의미한다. 이는 투자수준을 늘리는 것이 
투자성공의 불확실성을 줄여 경영자가 투자에 대해 갖는 비대칭적인 정보를 활용하여 이득을 얻기 힘들어지기 때문에 과소하게 투자할 유인이 있기 때문이다. 그러나 비상장주식거래 플랫폼을 통한 일반 투자자의 유입은 경영자가 과소투자할 유인을 줄일 것으로 보인다. 식 (16)을 만족하는 $i_{m}$ 에 대하여, 음함수의 정리(implicit function theorem)를 통해 $d i_{m} / d \sigma_{z}$ 를 계산하면 다음 식 (20)과 같다.

$$
\frac{d i_{m}}{d \sigma_{z}}=-\frac{\partial^{2} E\left[\pi_{m, 0}\right] / \partial i \partial \sigma_{z}}{\partial^{2} E\left[\pi_{m, 0}\right] / \partial i^{2}}
$$

식 (20)의 우변에서 분모는 0기의 기대이윤을 극대화하는 문제의 2계 조건에 해당한다. 2계 조건이 성립하여 우변의 분모가 음수라고 가정할 때, $d i_{m} / d \sigma_{z}$ 의 부호는 우변의 분자인 $\partial^{2} E[\pi] /$ $\partial i \partial \sigma_{z}$ 의 부호와 일치한다. 식 (21)은 이를 계산한 것이다.

$$
\frac{\partial^{2} E\left[\pi_{m, 0}\right]}{\partial i \partial \sigma_{z}}=\frac{1}{\sigma_{F} \sqrt{N+1}}\left(\frac{N+2}{4} q^{\prime}(i) I^{2}+\left(\frac{1}{N+2}-\frac{N+2}{4}\right) 2 q^{\prime}(i) q(i) I^{2}\right)>0
$$

식 (20)과 식 (21)에서 $\partial^{2} E\left[\pi_{m, 0}\right] / \partial i \partial \sigma_{z}$ 은 양의 값을 갖기 때문에 $d i_{m} / d \sigma_{z}$ 도 양의 값을 갖는다는 것을 알 수 있다. 이는 주식거래의 유동성이 증가할 경우, 경영자가 투자수준을 증가시킬 유인이 있다는 것을 보여준다. 그러나 마찬가지의 방법으로 $d i_{a l l} / d \sigma_{z}>0$ 임을 보일 수 있다. 만약 $d i_{m} / d \sigma_{z}>d i_{a l l} / d \sigma_{z}$ 라면, 비상장주식거래 플랫폼의 도입될 경우 이중 대리인 문제가 줄어들게 됨을 알 수 있다. $d i_{m} / d \sigma_{z}>d i_{a l l} / d \sigma_{z}$ 은 앞서 정의한 함수 $g(i)$ 를 통해 간접적으로 증명할 수 있다. 항상 $i_{m}<i_{a l l}$ 이 성립하므로, $i_{m}$ 과 $i_{a l l}$ 의 차이가 클수록 $g\left(i_{m}\right)$ 은 더 큰 값을 갖게 될 것이다. 이는 $g\left(i_{m}\right)$ 가 이중 대리인 문제의 정도를 나타내는 함수로 해석할 수 있음을 보여준다. 따라서 $\sigma_{z}$ 가 늘어날 때, $g\left(i_{m}\right)$ 가 줄어들게 되면 $i_{m}$ 와 $i_{a l l}$ 의 차이가 줄어들게 된다는 것을 의미한다. 식 $(22)$ 는 $d g\left(i_{m}\right) / d \sigma_{z}$ 를 계산한 것이다.

$$
\begin{aligned}
\frac{d g\left(i_{m}\right)}{d \sigma_{z}}= & \frac{N}{\sigma_{F} \sqrt{N+1}} \frac{1}{N+2} 2 q^{\prime}\left(i_{m}\right) q\left(i_{m}\right) I^{2} \\
& +\left(\frac{N \sigma_{z}}{\sigma_{F} \sqrt{N+1}} \frac{1}{N+2}\left(2 q^{\prime \prime}\left(i_{m}\right) q\left(i_{m}\right) I^{2}+2 q^{\prime}\left(i_{m}\right)^{2} I^{2}\right)+\sum_{k=1}^{N} s_{k} q^{\prime \prime}\left(i_{m}\right) I^{2}\right) \frac{d i_{m}}{d \sigma_{z}}
\end{aligned}
$$

식 (15)의 극대화 문제의 2계 조건이 성립할 때, $\sigma_{z}$ 가 충분히 작은 값을 갖는 상황에서 식 (22)는 음의 값을 갖게 되어 $d i_{m} / d \sigma_{z}>d i_{a l l} / d \sigma_{z}$ 가 성립한다. 이러한 분석의 결과는 비상장주식이 활발하게 거래되지 않고 있는 현재 상황에서 플랫폼을 통해 일반 투자자의 유입이 늘어나게 되면 이중 대리인 문제가 줄어들 수 있음을 보여준다. 이와 같은 결과가 나타나게 된 이유는 일반 투자자 유입으로 유동성이 증가하게 될 경우, 경영자가 비대칭 정보로 인해 얻을 수 있는 이점이 줄어들게 되기 때문이다. 이에 따라 경영자는 투자의 불확실성을 유지하여 주식거래를 통한 이득을 얻는 대신 기업 가치 상승을 통한 이득을 얻으려 할 유인이 커진다. 이로 인해 
Impact of Private Equity Trading Platforms on Firm Value and Corporate Governance

경영자는 전체 주주의 이윤이 극대화되는 수준에 근접하도록 투자수준을 늘리게 된다. 따라서 비상장주식거래 플랫폼을 통한 유통시장의 활성화는 이중 대리인 문제를 일부 해소하고 경영자의 장기적인 투자를 유도하여 비상장 중소기업의 성장에 도움을 줄 것으로 보인다.

\section{4. 정책 함의}

제 3장의 분석결과는 비상장주식거래 플랫폼이 활성화되었을 때, 비상장기업의 기업 가치 향상에 긍정적인 영향을 미친다는 사실을 보여준다. 따라서 본 절에서는 최근 활성화되고 있는 비상장주식거래 플랫폼에 대한 일반 투자자의 참여를 증대할 방안에 대해 논의한다. 제 2.1절에서 논의한 바와 같이, 일반 투자자가 비상장주식을 거래할 때, 접하는 애로사항은 진입장벽과 정보의 신뢰성의 두 가지로 정리할 수 있다. 진입장벽의 경우, 쉐어스포스트와 NPM, K-OTC PRO 등 일부 플랫폼이 전문투자자를 대상으로만 공개된다는 점에서 일반 투자자의 참여가 일부 제한된다고 볼 수 있다. 금융위원회는 비상장주식거래의 활성화가 저해되는 문제점으로 전문 투자자의 참여 유인이 미흡함을 지적하며, 전문투자자 전용 플랫폼의 필요성을 역설했고, 그 결과 도입된 것이 $\mathrm{K}-\mathrm{OTC} \mathrm{PRO}$ 이다. 이는 비상장주식에 대한 투자가 벤처캐피탈(VC; venture capital) 펀드에 의해 주로 이루어진다는 점에 기인한다(Block et al., 2019). VC가 투자를 통해 유망한 비상장기업의 성장을 끌어낸 후, 적절한 투자금의 회수가 필요하다. 대표적인 방법은 투자기업의 인수합병 $(\mathrm{M} \& \mathrm{~A})$ 이나 기업공개(IPO)이지만, 실패의 가능성이 크다. 비상장주식거래 플랫폼은 $\mathrm{VC}$ 에게 투자금 회수의 효과적인 대안이 될 수 있다. $\mathrm{VC}$ 의 효율적인 투자금 회수가 해당 펀드의 새로운 투자를 촉진한다는 점에서 긍정적인 순환이 발생할 가능성이 크다. 이러한 점에서 초기 비상장주식거래 플랫폼은 해당 거래에 대한 수요가 확실하고 거래 규모가 큰 전문투자자를 거래 참여자로 포섭하는 것이 적절하다. 이에 따라 $\mathrm{K}-\mathrm{OTC} \mathrm{PRO}$ 는 다양한 혜택과 진입장벽 완화를 통해 전문투자자를 모집하였다.

그러나 최근 일반 투자자들의 비상장주식거래에 관한 관심이 증가하고 있다는 점에서 증권사들의 비상장주식거래 플랫폼 구축이 새로운 수요를 창출할 가능성이 존재한다. 이와 관련하여 최근 시장에 공개되고 있는 증권사, 핀테크 기업 등이 운영하는 플랫폼은 앞선 플랫폼들과는 반대로 일반 투자자에 대한 접근성을 높이고 있다는 점에서 긍정적 함의를 제공한다. 일반적으로 증권사가 비상장주식거래 중개에 적극적으로 나설 가능성은 작다. 초대형 투자은행 육성 방안의 하나로 2017년 7월 개정된 자본시장법 시행령에 종합투자회사의 업무 범위에 비상장주식 내부주문집행 업무가 추가되었음에도,17) 비상장주식에 대한 적은 수요와 높은 위험, 시스템 구축과 인력 채용 부담 등을 이유로 증권사들은 비상장주식거래의 중개에 소극적인 상황이다. 따라서 비상장주식거래에 대한 시스템 구축이나 인력 채용 등의 비용에 대한 정책적 지원이 뒷받침된다면 비상장주식에 대한 일반 투자자의 유입이 더욱 활발하게 이뤄질 수 있을 것이다. 또한, 일반 투자자들의 비상장주식에 대한 접근성을 높이기 위해서는 모바일 애플리

17) “비상장주식 거래 허용했는데... 증권사들이 외면하는 까닭은", 한국경제, 2019년 9월. 
한국증권학회지 제49권 4호 (2020)

케이션을 기반으로 한 플랫폼의 구축에 대한 지원이 필요하다. 이를 위해서는 비대면 거래 허용 등 법률적 지원이 필요할 것으로 보인다.

투명한 정보공개의 경우, 블록체인 기술의 접목을 해결책으로 제시할 수 있다. 블록체인 기술은 거래에 관한 정보를 참여자들이 실시간으로 투명하게 공유하게 함으로써, 증권시장에서 거래의 효율성과 투명성을 동시에 개선할 수 있는 기술로 주목받고 있다(Park and Ryu, 2019; Jang, 2017). 특히, 블록체인 기술이 갖는 실시간 투명성은 주식거래의 유동성을 증대하여 기업 가치와 지배구조에 상당한 영향을 미칠 것으로 전망된다(Yermack, 2017). 이에 따라 전 세계 금융시장 에서 블록체인 기술을 거래시스템에 도입하는 노력이 이어지고 있다. 대표적으로 미국은 버몬트(Vermont), 애리조나(Arizona), 네바다(Nevada) 등에서 블록체인의 기록 및 서명의 법적 효력을 인정하여 법적 기반을 제공하거나 블록체인을 통한 거래에 대해 면세 혜택을 제공하는 법안을 통과시키는 등 블록체인을 통한 증권 거래에 관한 법률 및 정책적 지원을 제공하고 있다.18) 이를 바탕으로 미국 나스닥은 사설시장에 블록체인 기반 시스템인 '나스닥 링크(NASDAQ Linq)'를 도입해 비상장주식을 발행했으며, '공개 시장(public market) 기술 도입'도 검토 중이다.19)

증권사와 핀테크 기업이 운영하는 플랫폼에서도 블록체인 기술의 도입을 적극적으로 검토하고 있다. '증권플러스 비상장'은 처음부터 블록체인 기술을 기반으로 공개되었으며, 코스콤의 ‘비마이유니콘’은 플랫폼을 공개한 이후, 2020년 상반기 중 블록체인 기술을 도입할 예정이라고 발표했다.20) 이처럼 비상장주식거래 플랫폼에 블록체인 기술을 접목하면 실시간 투명성이 확보되어 일반 투자자의 애로사항이 해소되고 그로 인해 비상장주식거래의 유동성을 증대시킬 것으로 보인다. 그러나 국내에서는 블록체인 기술에 대한 법률적·정책적 제약이 있어 활용이 자유롭지 못하다. 특히, 개인정보보호에 관해 다른 국가에 비해 엄격한 기준을 적용한다는 특징은 보안기술에 기반을 두고 개인정보를 활용하는 것이 필수적인 블록체인 기술의 활용을 제한한다 (Chung, 2016). 이로 인해 국내 블록체인 산업은 은행원을 중심으로 독자적인 핀테크 기업과의 협업을 통해 일부 사용되고 있을 뿐, 다양한 방향에서 활용성이 검토되지는 못하고 있다. 또한, 2019년 11월 데이터 3법으로 불리는 개인정보보호법, 신용정보법, 정보통신망법 개정안의 본회의 통과가 무산됨에 따라 국내 블록체인 산업의 활성화가 제대로 이루어지지 못하고 있다.21) 따라서 관련 법률 개정에 관한 해외사례를 참고하여 블록체인 산업의 활용성을 높이기 위한 논의가 지속해서 진행될 필요가 있다.

18) 유거송-김경훈, “블록체인”, KISTEP 기술동향브리프, 한국과학기술기획평가원, 2018-01호(2018), pp. 1-33.

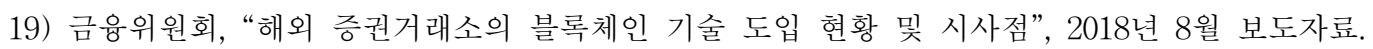

20) “코스콤 vs. 두나무 “비상장 주식, 블록체인으로 안전거래”, 팍스넷뉴스, 2020년 1월.

21) “미래산업 원유” 데이터 3법 또 불발...국회논의 1년 됐는데 몰라서 통과 못시켜?”, 조선비즈, 2019년 11월. 
Impact of Private Equity Trading Platforms on Firm Value and Corporate Governance

\section{5. 결론}

본 연구는 비상장주식거래에 관한 관심이 증대됨에 따라 최근 활성화되고 있는 비상장주식거래 플랫폼의 현황과 기대효과를 개괄적으로 제시하고, 이에 대한 모형을 설계하여 도입 효과를 분석한다. 비상장주식거래 플랫폼은 비상장기업의 가치급등과 그에 따른 수요의 증가로 최근 규모가 증가하고 있다. 플랫폼은 진입장벽을 점차 완화함으로써 비상장주식거래의 유동성을 높이고 있다. 특히 증권사와 핀테크 업체에서 최근 공개한 플랫폼들의 경우, 기존 플랫폼들보다 진입장벽을 획기적으로 낮추고, 모바일 애플리케이션과 블록체인 등의 기술을 통해 일반 투자자의 접근성을 개선했다는 특징을 보인다. 이는 전문 기관투자자를 중심으로 거래되던 비상장주식 거래시장에 일반 소매투자자가 유입될 가능성을 내포한다는 점에서 비상장주식의 유동성을 증가시킬 것으로 보인다. 유동성의 증가가 기업 가치와 기업지배구조에 긍정적인 영향을 미친다는 다수의 선행연구는 비상장주식거래 플랫폼의 활성화가 비상장기업에 유리하게 작용할 수 있음을 시사한다.

본 논문에서는 비상장주식거래 플랫폼의 활성화가 비상장기업의 자본투자 의사결정에 미치는 영향을 분석한다. 이를 통해 플랫폼이 활성화되어 유동성이 높아지면 경영자가 외부 주주를 대변하는 수준까지 장기적인 투자수준을 높이고, 이에 따라 기업 가치 향상에 긍정적인 영향을 미친다는 것을 보였다. 비상장기업 가치 상승에 유동성 크기의 증가가 중요한 요소라는 분석 결과를 바탕으로 모바일 애플리케이션과 블록체인 기술의 활용 등 비상장주식거래 플랫폼에 대한 일반 투자자의 참여를 증대시킬 방안을 제시한다. 그러나 본 논문은 비상장주식거래 플랫폼이 비교적 최근 활성화되었다는 점에서 관련 자료의 충분한 축적이 이루어지지 않아 실증적인 분석을 제시하지 못한다는 한계를 갖는다. 따라서 자료가 충분히 축적된 이후에 본 논문에서 논의한 내용에 관한 실증적인 연구가 필요하다. 
한국증권학회지 제49권 4호 (2020)

\section{References}

Alvarez, R., M. Jara, and C. Pombo, 2018, Do Institutional Blockholders Influence Corporate Investment? Evidence from Emerging Markets, Journal of Corporate Finance, Vol. 53, pp. 38-64.

Ashraf, R., H. Li, and H. E. Ryan Jr., 2020, Dual Agency Problems in Family Firms: Evidence from Director Elections, Journal of Corporate Finance, Vol. 62 (101556), pp. 1-22.

Bharath, S. T., S. Jayaraman, and V. Nager, 2013, Exit as Governance: An Empirical Analysis, Journal of Finance, Vol. 68 (6), pp. 2515-2547.

Block, J., C. Fisch, S. Vismara, and R. Andres, 2019, Private Equity Investment Criteria: An Experimental Conjoint Analysis of Venture Capital, Business Angels, and Family Offices, Journal of Corporate Finance, Vol. 58, pp. 329-352.

Borisova, G., K. John, and V. Salotti, 2013, The Value of Financing Through Cross-Border Asset Sales: Shareholder Returns and Liquidity, Journal of Corporate Finance, Vol. 22, pp. 320-344.

Cheung, W. M., R. Chung, and S. Fung, 2015, The Effects of Stock Liquidity on Firm Value and Corporate Governance: Endogeneity and the REIT Experiment, Journal of Corporate Finance, Vol. 35, pp. 211-231.

Choi, H. J., and D. W. Lee, 2019, Does the SME Exchange Properly Function as a Growth Market? A Look Through its Correlation with Private-Firm Growth, Korean Journal of Financial Studies, Vol. 48 (4), pp. 467-496.

Chung, S. H., 2016, Legal Issues for the Introduction of Distributed Ledger Based on Blockchain Technology: Focused on the Financial Industry, Korean Journal of Financial Law, Vol. 13 (2), pp. 107-138.

Edmans, A., 2009, Blockholder Trading, Market Efficiency, and Managerial Myopia, Journal of Finance, Vol. 64 (6), pp. 2481-2531.

Eom, K. S., J. H. Park, and J. A. Yoon, 2009, The Korean OTC Stock Market: Micro and Macrostructure Analysis, Asian Review of Financial Research, Vol. 22 (4), pp. 33-62.

Fang, V. W., T. H. Noe, and S. Tice, 2009, Stock Market Liquidity and Firm Value, Journal of Financial Economics, Vol. 94 (1), pp. 150-169.

Gerken, W. C., 2014, Blockholder Ownership and Corporate Control: The Role of Liquidity, Quarterly Journal of Finance, Vol. 4 (1), pp. 1-36.

Jang, K. J., 2017, The a Study on Innovative Financial Services of Business Models Using BlockChain Technology, e-Business Studies, Vol. 18 (6), pp. 113-130.

Kang, H. C., 2014, Active Family Management and Firm Performance in the Large Business Group, Asian Review of Financial Research, Vol. 27 (1), pp. 141-176. 
Impact of Private Equity Trading Platforms on Firm Value and Corporate Governance

Kang, H. C., and K. S. Park, 2011, The Decision to go Public by Family Firms, Asian Review of Financial Research, Vol. 24 (1), pp. 41-89.

Kang, H. C., K. S. Park, and H. S. Jang, 2006, Determinants of Family Ownership: The Choice between Control and Performance, Korean Journal of Financial Studies, Vol. 35 (6), pp. 39-75.

Kyle, A. S., 1985, Continuous Auctions and Insider Trading, Econometrica, Vol. 53 (6), pp. $1315-1335$.

Lee, H. C., 2016, Institutional Trading, Stock Liquidity, and Firm Value, Korean Journal of Financial Studies, Vol. 45 (5), pp. 1131-1165.

Maug, E., 1998, Large Shareholders as Monitors: Is There a Trade-off between Liquidity and Control?, Journal of Finance, Vol. 53 (1), pp. 65-98.

Park, D., and D. Ryu, 2019, Blockchain in Health Insurance: Sharing Medical Information and Preventing Insurance Fraud, Korean Journal of Financial Studies, Vol. 48 (4), pp. 417-447.

Park, J. J., and K. S. Eom, 2008, The Characteristics of the Illiquidity Premium, Measured Via Spread, Korean Journal of Finance, Vol. 21 (2), pp. 77-114.

Park, S. Y., 2016, The Relation between Family Control and Corporate Investment Efficiencies, Review of Accounting and Policy Studies, Vol. 21 (5), pp. 51-70.

Pindado, J., I. Requejo, and C. de la Torre, 2011, Family Control and Investment-Cash Flow Sensitivity: Empirical Evidence from the Euro Zone, Journal of Corporate Finance, Vol. 17, pp. 1389-1409.

Villalonga, B., and R. Amit, 2006, How do Family Ownership, Management, and Control Affect Firm Value? Journal of Financial Economics, Vol. 80, pp. 385-417.

Yermack, D., 2017, Corporate Governance and Blockchains, Review of Finance, Vol. 21 (1), pp. $7-31$. 